\title{
ACADEMIC WEB TOOL FOR WEIGHTAGE DETERMINATION OF RANKING PARAMETERS
}

\author{
K. Abhishek ${ }^{1}$, P. Suchit ${ }^{*}$, G. Savita ${ }^{2}$,S. Kalgi ${ }^{1}$, K. S. Beena ${ }^{2}$ \\ ${ }^{1}$ INFLIBNET Centre, Gandhinagar, Gujarat, India - abhishek@inflibnet.ac.in \\ ${ }^{2}$ Dept. of Computer Science, Gujarat University, Gujarat, India - (drsavitagandhi, suchitpurohit,kalgishah7, \\ beenamanojkumaar)@gmail.com
}

KEY WORDS: Higher Education, Ranking Systems, Ranking Parameters, University, Parameters Weightage, NIRF

\begin{abstract}
:
Indian education system, third largest of education system in the world comprises of Universities, Colleges, Technical institutions, Institutions of National importance etc. Choosing the right institution for academic activity is always a challenging job. In this context, ranking of Universities play a big role in shaping opinions of current potential students, parents, employers and government about the quality of educational institutions. National Institutional Ranking Framework(NIRF), an initiative of MHRD is the ranking system of India to rank all institutions of higher education in India. The current framework of NIRF works on approved set of parameters and assigned weightage. We propose a user defined framework with our own set of parameters based on survey of national and international ranking system. Weightages are calculated (algorithm based) dynamically by registering the preferences of different stakeholders. A web-portal was developed to capture the responses of different stakeholders, calculate weightages and can be used to assign ranking to the universities on the basis of end-user preferences. The portal was tested by registering responses of school students, colleges students, faculties of universities and parents and calculating the weightages for each parameter run time. This paper presents our methodology ,results of data analytics of survey and performance of our algorithm in evaluating the weightages, importance of parameters and perception of stakeholders of institutes at various levels.
\end{abstract}

\section{INTRODUCTION}

Higher education ranking and/or university ranking systems are mechanism that use available information to rank institutions of higher education based on indicators or criteria defined by ranking agencies. (Swail 2011) University rankings are definite set of institutions, comparatively ranked according to a common set of parameters in particular order. In majority of ranking systems, institutions' comparison data are collected in the form of parameters; data of each parameter are scored and scores from each parameter are weighted. Rankings are not just a collection of parameters; instead they are weighted aggregation of parameters. (Marguirite Clarke 2007) Ranking play a significant role in framing the preferences of potential stakeholders such as students, faculties, parents and government regarding the quality of higher education institutes. Ranking systems are an aid through which the universities can anticipate their position and work towards improvement of it. (Alma, Coşkun, and Övendireli 2016). In recent years many university ranking systems have been developed. Each framework differs from each other in number, type of parameters and weightage assigned to them. Table1 presents summary of existing international and national ranking frameworks. Though international ranking systems are justified in the scenario of globalisation, it totally ignores country and region-specific circumstances. For this purpose, national systems are constructed. National systems are more capable of handling regional and cultural factors as they are constructed for country specific purposes. ${ }^{*}$

In this view, NIRF was developed in 2014-2015 with the purpose of development of set of parameters relevant to Indian context. These parameters are organized in to five main categories furthered divided in to suitable sub parameters. Each has parameter having a suitable weightage distribution(Table2).
Overall score is computing for each sub parameters based on allocated weightage which can take a maximum value of 100 . The institutes can then be ranked based on their obtained scores (https://www.nirfindia.org). From study of NIRF ranking system, it was understood that the parameters and their weightage are taken on broader prospective considering the fact that there are different kind of Indian Institutes are providing higher education in India. But a broader perspective of parameters cannot be applied to a spectrum of universities due to the diversity of infrastructure among different institutions, specially due to urban and rural surroundings; diversity on nature of institutions like polytechnic, engineering, nontechnical etc.; diversity on nature of courses being offered by the Institutions like graduate, post-graduate etc.

We propose derived cum enhancement to the existing system (NIRF and other ranking agencies) in a way that preferences of individual stakeholders towards higher education facilities are taken into account for dynamic weightage of the parameters. We propose a framework defining our own set of parameters based on survey of national and international ranking system. Weightages are calculated (algorithm-based) dynamically by registering the preferences of different stakeholders. To aid the data capturing, analysis and weightage calculations an online web portal has been proposed. The main advantage of this system is involvement of real end-user because ultimately learners / students are key components of universities hence the input of learners should play a vital role in framing any structure for university.

\footnotetext{
* Corresponding author
} 
The International Archives of the Photogrammetry, Remote Sensing and Spatial Information Sciences, Volume XLII-5, 2018

ISPRS TC V Mid-term Symposium "Geospatial Technology - Pixel to People", 20-23 November 2018, Dehradun, India

\begin{tabular}{|c|c|c|c|}
\hline Ranking System & $\begin{array}{l}\text { International } \\
\text { / National }\end{array}$ & Parameters & Weightage \\
\hline \multirow{7}{*}{ US News \& World Report } & \multirow{7}{*}{ National } & Graduation and retention rates & $22.5 \%$ \\
\hline & & $\begin{array}{ll}\text { Undergraduate } & \text { academic } \\
\text { reputation } & \\
\end{array}$ & $22.5 \%$ \\
\hline & & Faculty resources & $20 \%$ \\
\hline & & Student selectivity & $12.5 \%$ \\
\hline & & Financial resources & $10 \%$ \\
\hline & & Graduation rate performance & $7.5 \%$ \\
\hline & & Alumni giving rate & $5 \%$ \\
\hline \multirow{4}{*}{$\begin{array}{l}\text { Academic Ranking of World Universities } \\
\text { http://cwcu.sjtu.edu.cn/arwu.html }\end{array}$} & \multirow{4}{*}{ International } & Quality of Education & $10 \%$ \\
\hline & & Quality of Faculty & $40 \%$ \\
\hline & & Research Output & $40 \%$ \\
\hline & & Per Capita Performance & $10 \%$ \\
\hline \multirow{5}{*}{$\begin{array}{l}\text { Times Higher Education World University Ranking } \\
\text { https://www.timeshighereducation.com/world-university- } \\
\text { rankings }\end{array}$} & \multirow{5}{*}{ International } & $\begin{array}{lll}\begin{array}{l}\text { Teaching } \\
\text { environment) }\end{array} & \text { (the learning } \\
\end{array}$ & $30 \%$ \\
\hline & & $\begin{array}{l}\text { Research (volume, income and } \\
\text { reputation) }\end{array}$ & $30 \%$ \\
\hline & & Citations (research influence) & $30 \%$ \\
\hline & & $\begin{array}{l}\text { International Outlook (staff, } \\
\text { students, research) }\end{array}$ & $7.5 \%$ \\
\hline & & $\begin{array}{l}\text { Industry income } \quad \text { (knowledge } \\
\text { transfer) }\end{array}$ & $2.5 \%$ \\
\hline \multirow{6}{*}{$\begin{array}{l}\text { Quacquarelli Symonds World University Rankings } \\
\text { http://www.qs.com/rankings/ }\end{array}$} & \multirow{6}{*}{ International } & Academic Reputation & $40 \%$ \\
\hline & & Employer Reputation & $10 \%$ \\
\hline & & Faculty/Student Ratio & $20 \%$ \\
\hline & & Citations per faculty & $20 \%$ \\
\hline & & International Faculty Ratio & $5 \%$ \\
\hline & & International Student Ratio & $5 \%$ \\
\hline \multirow{6}{*}{ University Ranking by Academic Performance } & \multirow{6}{*}{ National } & Article & $21 \%$ \\
\hline & & Citation & $21 \%$ \\
\hline & & Total Document & $10 \%$ \\
\hline & & Article Impact Total & $18 \%$ \\
\hline & & Citation Impact Total & $15 \%$ \\
\hline & & International Collaboration & $15 \%$ \\
\hline \multirow{5}{*}{$\begin{array}{c}\text { Higher Education Commission of Pakistan } \\
\text { http://www.hec.gov.pk/english/universities/Pages/University- } \\
\text { Ranking.aspx }\end{array}$} & \multirow{5}{*}{ National } & Quality Assurance & $15 \%$ \\
\hline & & $\begin{array}{l}\text { Teaching Quality (Teaching / } \\
\text { Learning environment) }\end{array}$ & $30 \%$ \\
\hline & & Research & $41 \%$ \\
\hline & & Finance and Facilities & $10 \%$ \\
\hline & & $\begin{array}{l}\text { Social Integration / Community } \\
\text { development }\end{array}$ & $4 \%$ \\
\hline
\end{tabular}

Table1: Summary of parameters of ranking frameworks

\begin{tabular}{|l|l|l|l|}
\hline Ranking System & International & Parameters & Weightage \\
\hline \multirow{4}{*}{ National Institutional Ranking Framework } & & Teaching, Learning and Resources & $30 \%$ \\
\cline { 3 - 4 } & \multirow{3}{*}{ National } & Research and Professional Practice & $30 \%$ \\
\cline { 3 - 4 } & & Graduation Outcomes & $20 \%$ \\
\cline { 3 - 4 } & & Outreach and Inclusivity & $10 \%$ \\
\cline { 3 - 4 } & & Perception & $10 \%$ \\
\hline
\end{tabular}

Table2. NIRF ranking parameters with their weightage 


\section{METHODOLOGY OF PROPOSED SYSTEM}

To execute the objectives aimed for in this study the methodology described in Figure 1 was adapted. The following sections describe the work done as per the framed methodology.

Prepare survey questionnaire
$\downarrow$
Data collection from real stakeholder and supportive
stakeholders
$\downarrow$
$\downarrow$
Generate report of survey analytics
for each parameter using decision tree framework
$\downarrow$
Assign weightage to parameters

Figure 1. Methodology

\section{IDENTIFICATION OF PARAMETERS}

Following the survey of existing ranking systems and taking into account the Indian context we zeroed down on following parameters:

1. Teaching Learning

- Course and Teaching

- Library Facilities

- Laboratory Facilities

- IT Facilities

- Room Facilities

2. Research (excluded from school students and parents)

- Research Orientation

- External Research Income

3. Infrastructure

- Basic facilities and cleanliness in the campus and department

- Add-on Facilities in the campus

- Transportation and Medical Facilities

- Hostel Facilities

- Canteen Facilities

4. Support Activities

- Placement-Internship Facilities

- Sports, Extra Curricular and Co-Curricular Activities

- Financial Aids

5. International Orientation

- Opportunities and Support for study in abroad

\section{QUESTIONNAIRE, DATA COLLECTION AND SURVEY REPORTS}

The different stakeholders for any institutes have their own perception towards the facilities offered by higher education institutes. For example, a parent may give priority to support activities for higher placement whereas a school student may look for institute with good infrastructure. Therefore, questionnaire was prepared from the perspective of different stakeholders. The questions were framed so as to capture data that the institution can easily provide, easily obtain from stake holders and easily verifiable when needed. The questionnaire was prepared in such a way that different diversities like board, stream gender, discipline degree etc. gets accommodated. This was necessary to incorporate and observe the correlation between different categories and their preferences towards parameters. The questionnaire was written in English and was conceived for the respondents to be able to give priorities to the given parameters according to his/her preference. A sample questionnaire for school students is attached in Appendix 1. Questionnaire was prepared for following stakeholders:
1. High School Students
2. College Students
3. Faculties
4. Parents

\subsection{Data collection}

In the first data collection drive, survey was carried out with 450 school students participating. A quota selection was selected to determine the research sample. The respondents were High school students of $12^{\text {th }}$ standard from different schools of Ahmedabad. 40 responses were discarded due to incompleteness of data and/or improper data. After this reduction, respondent numbers were considered for further processing.

In the second phase, a similar survey was carried out with 115 college students participating. The respondents were College students from different institutes .35 responses were discarded due to incompleteness of data and/or improper data. After this reduction, respondent numbers considered for further processing.

In other phase, survey was carried out with 80 college/university faculties participating. The respondents were Institute faculties from different institutes listed in following below table. 28 responses were discarded due to incompleteness of data and/or improper data. After this reduction, respondent numbers considered for further processing.

Figure 2 to Figure 5 illustrates distribution of respondents as per different categories.

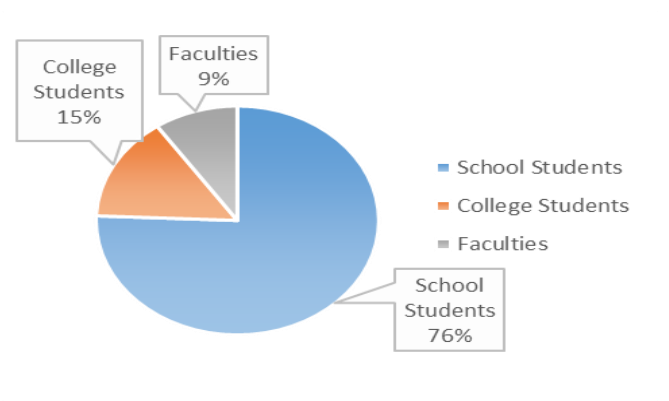




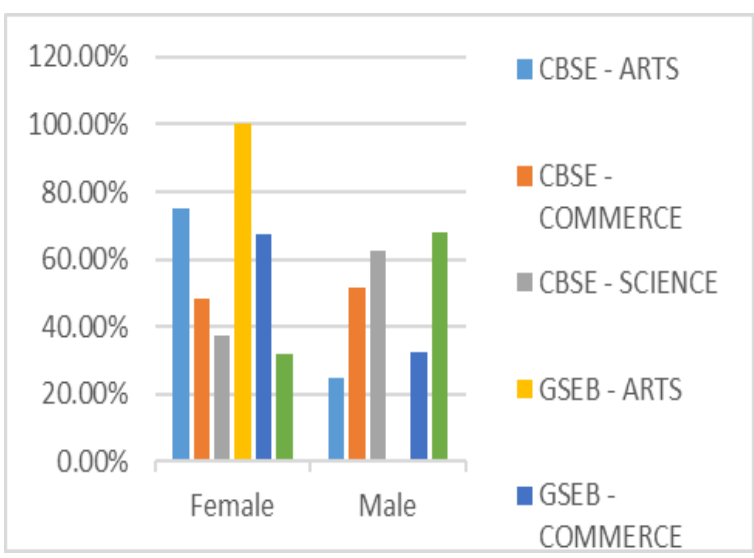

Figure 3. Distribution of data for school students'

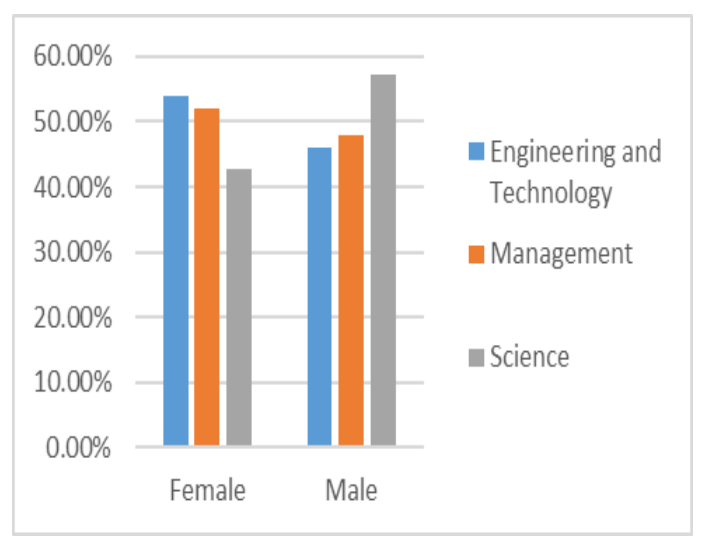

Figure 4. Distribution of data for college students'

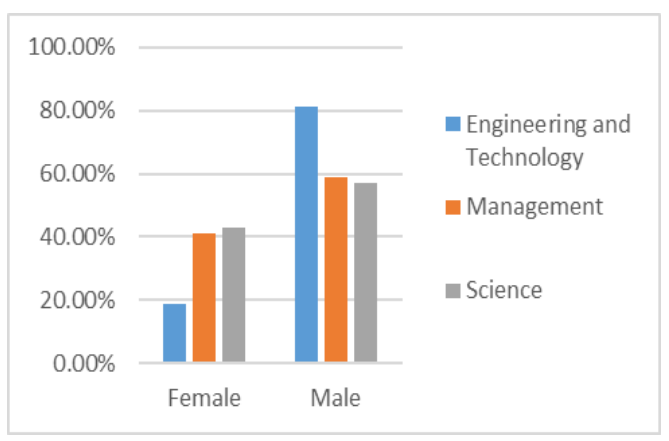

Figure 5. Distribution of data for faculties'

\section{TEST OF INDEPENDENCE}

To understand the correlation between preferences and different categories of stakeholders, test of independence using chi square method was carried out (Gingrich 2004). The two variables for test of independence were chosen as:

Variable 1: Category of respondents ;Variable 2: Assigning the parameters at a particular priority

1. The hypothesis was formulated as:

$H_{0}$ : No dependence between two variables

$H_{1}$ : Some dependence between the two variables

2. The chi square test statistic is evaluated as:

$$
x^{2}=\sum_{i} \frac{\left(O_{i}-E_{i}\right)^{2}}{E_{i}}
$$

where $\quad X^{2}=$ chi square statistic; $O_{i}=$

Observed frequencies; $E_{i}=$ Expected frequencies

3. The degree of freedom for the test is given by equation (2).

$$
\mathrm{df}=(\mathrm{r}-1)(\mathrm{c}-1)
$$

where $\mathrm{r}=$ number of categories; $\mathrm{c}=$ number of parameters

4. Error was taken as 0.05
5. If p-value $<0.05$, accept the null hypothesis else accept.

The chi-square statistics in the form of p-value was observed for all the main parameters and all the priorities (Table 3). The following conclusions were drawn from the observations:

1. The dependence was reflected only in selection of a particular parameter at highest and lowest priority.

2. From the survey of school students, strong correlation was obtained between gender of student and selection of teaching learning at highest priority

3. The data of college students clearly shows correlation between discipline of student and selection of research as highest priority.

4. A correlation was obtained between selection of International Orientation parameter at last priority. For school students, it was found to be dependent on gender as well as stream with the strength of correlation greater for stream (0.002) as compared to gender (0.032). For college students and faculties, it was found to be dependent on discipline.

5. There was no correlation found between selection of parameters at intermediate priorities and respondent categories. 


\begin{tabular}{|c|c|c|c|c|}
\hline Stakeholder & Variable1 & Variable2 & p-value & Null Hypothesis \\
\hline \multirow[t]{12}{*}{ School Student } & \multirow[t]{4}{*}{ Gender } & Priority1 Teaching Learning & 0.005 & Rejected \\
\hline & & Priority2 Support Activities & 0.098 & Accepted \\
\hline & & Priority3 Infrastructure & 0.168 & Accepted \\
\hline & & Priority4 International Orientation & 0.038 & Rejected \\
\hline & \multirow[t]{4}{*}{ Board } & Priority1 Teaching Learning & 0.278 & Accepted \\
\hline & & Priority2 Support Activities & 0.580 & Accepted \\
\hline & & Priority3 Infrastructure & 0.346 & Accepted \\
\hline & & Priority4 International Orientation & 0.456 & Accepted \\
\hline & \multirow[t]{4}{*}{ Stream } & Priority1 Teaching Learning & 0.122 & Accepted \\
\hline & & Priority2 Support Activities & 0.419 & Accepted \\
\hline & & Priority3 Infrastructure & 0.695 & Accepted \\
\hline & & Priority4 International Orientation & 0.002 & Rejected \\
\hline \multirow{10}{*}{$\begin{array}{l}\text { College } \\
\text { Students }\end{array}$} & \multirow[t]{5}{*}{ Gender } & Priority1 Research & 0.869 & Accepted \\
\hline & & Priority2 Teaching Learning & 0.967 & Accepted \\
\hline & & Priority3 Support Activities & 0.374 & Accepted \\
\hline & & Priority4 Infrastructure & 0.621 & Accepted \\
\hline & & Priority5 International Orientation & 0.279 & Accepted \\
\hline & \multirow[t]{5}{*}{ Discipline } & Priority1 Research & 0.035 & Rejected \\
\hline & & Priority2 Teaching Learning & 0.725 & Accepted \\
\hline & & Priority3 Infrastructure & 0.013 & Rejected \\
\hline & & Priority4 Support Activities & 0.045 & Rejected \\
\hline & & Priority5 International Orientation & 0.082 & Accepted \\
\hline \multirow[t]{10}{*}{ Faculties } & \multirow[t]{5}{*}{ Gender } & Priority1 Teaching Learning & 0.215 & Accepted \\
\hline & & Priority2 Teaching Learning & 0.562 & Accepted \\
\hline & & Priority3 Research & 0.061 & Accepted \\
\hline & & Priority4 Support Activities & 0.082 & Accepted \\
\hline & & Priority5 International Orientation & 0.351 & Accepted \\
\hline & \multirow[t]{5}{*}{ Discipline } & Priority1 Teaching Learning & 0.825 & Accepted \\
\hline & & Priority2 Research & 0.291 & Accepted \\
\hline & & Priority3 Infrastructure & 0.419 & Accepted \\
\hline & & Priority4 Support Activities & 0.686 & Accepted \\
\hline & & Priority5 International Orientation & 0.010 & Rejected \\
\hline
\end{tabular}

Table 3: chi-square test statistics

\section{WEIGHTAGE CALCULATION}

Once the priority of the each and every parameter is registered by the different stakeholders, the weightage for each parameter is calculated using the decision tree approach. A decision tree is a directed tree graph. The root node is the source, and every node thereafter is either a decision node or an end node. Decision nodes have multiple outward-pointing edges, and there is a splitting rule at each node governing the significance of each edge leading away (Leung 2007). Our proposed decision tree approach works on the principle of setting main parameters as the root node and sub-parameters splitted at the main parameters. The weights are assigned by calculating the relative frequency at each level. Shows a decision tree for a sample of 25 for priority 1 . Out of 2514 have selected Teaching and learning, 7 have selected support activities, 2 have selected infrastructure and 2 as international orientation at priority one. Decision tree for weightage determination of main parameters shows in Figure 5. Therefore, weights of parameters are calculated as $0.56,0.28,0.08$ and 0.08 respectively. At next level, taking main parameter as root, sub-parameters are splitted and weights calculated as shown in Figure 8 . 


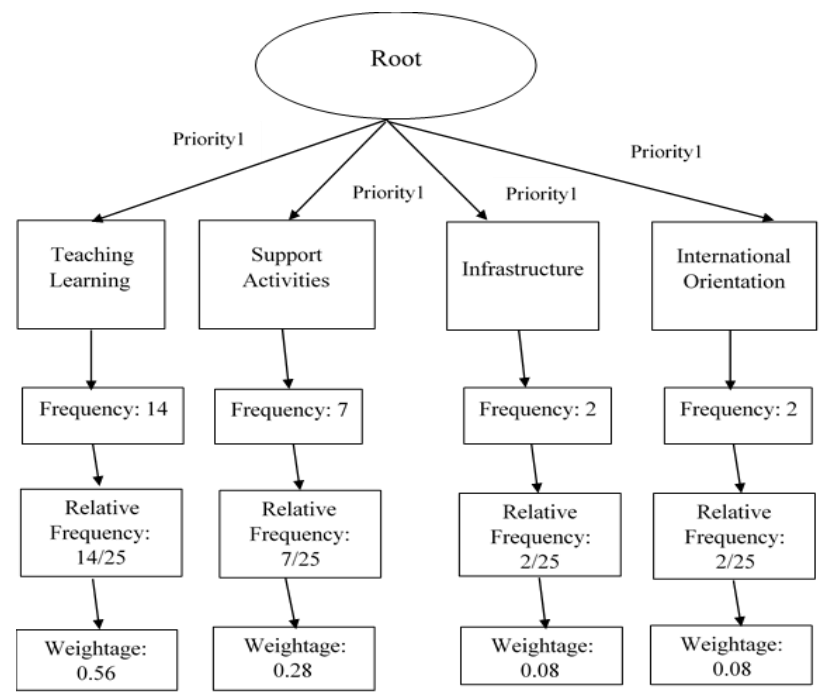

Figure 7. Weightage calculation of main parameters

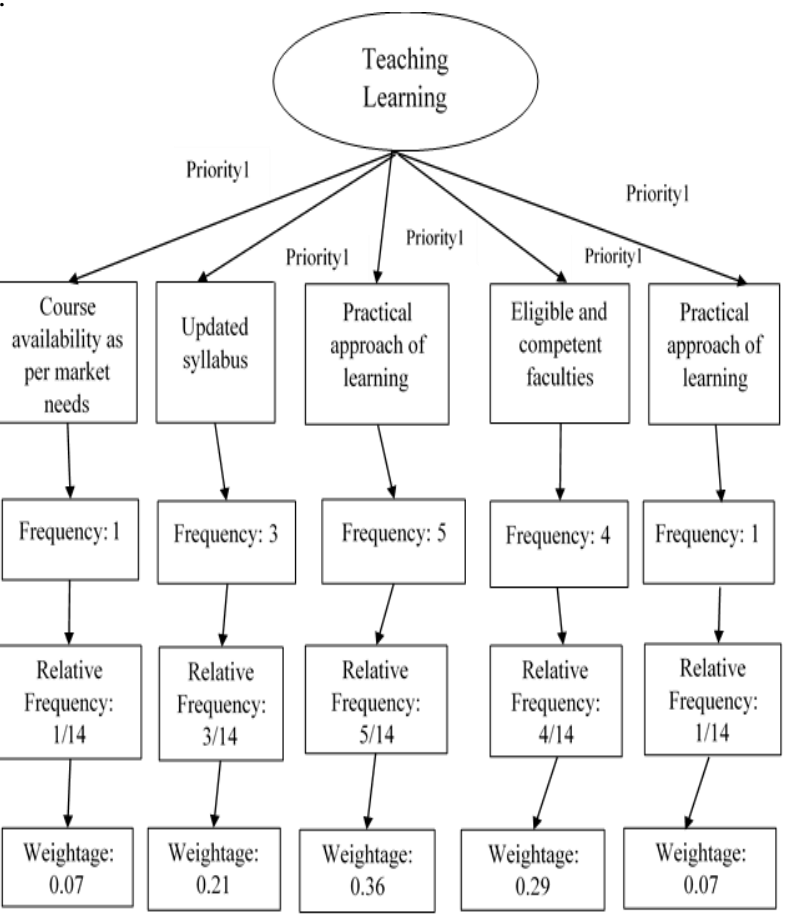

Figure 8. Weightage calculation of sub parameters

\section{IMPLEMENTATION OF WEB PORTAL}

\subsection{Hardware requirements}

\begin{tabular}{|l|l|}
\hline Hard Disk space & Minimum 1.5 GB space \\
\hline RAM & Minimum 1 GB \\
\hline
\end{tabular}

Weightage Assignment priority1

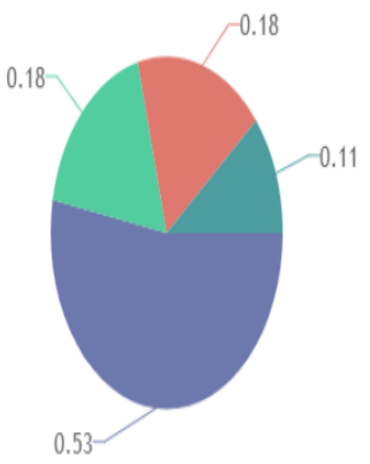

Teaching Learning Infrastructure Support Activities International Orientation

\begin{tabular}{|l|l|}
\hline CPU & Minimum Pentium 4, 3.2 GHz \\
\hline Table 4. Hardware requirements
\end{tabular}

\subsection{Software requirements}

\begin{tabular}{|l|l|}
\hline Operating System & Windows XP onwards \\
\hline $\begin{array}{l}\text { Webserver and Database } \\
\text { server }\end{array}$ & WAMP \\
\hline Editor & Notepad++ \\
\hline Browser & Google Chrome \\
\hline
\end{tabular}

Table 5. Software requirements

\subsection{Features of web portal}

-Provide easy to use interface to conduct online survey of all stakeholders regarding their perception for higher education institute facilities.

- Generate graphical and tabular survey reports.

-Provide facility of searching and filtering from the database

-Implementation of algorithm for chi-square statistics and generate reports on correlation

-Calculate weightage of parameters and sub parameters.

-Manage parameters

-Manage Stakeholders

-Provide provision for calculating aggregated score 


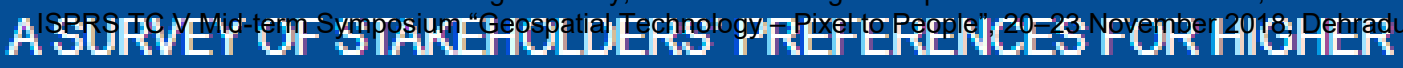 EDUCATION INSTITUTE FACILITIES}

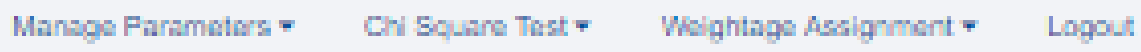

\section{Chi Square Test of Independence for School Students}

\begin{tabular}{|c|c|c|c|c|c|}
\hline \multicolumn{6}{|c|}{ Display Results } \\
\hline & $\begin{array}{l}\text { Tosohlng } \\
\text { Lasarnlng }\end{array}$ & Infrastrusture & support Aottyitios & $\begin{array}{l}\text { Intarnational } \\
\text { orlontation }\end{array}$ & Total \\
\hline Male & $\mathrm{BS}$ & 33 & 89 & 25 & 216 \\
\hline Fomale & 45 & 26 & 84 & 3 & 154 \\
\hline Other & 0 & 0 & 0 & 0 & 0 \\
\hline Total & 114 & 59 & 173 & B4 & 410 \\
\hline
\end{tabular}

P-welua [Chi squan walua]

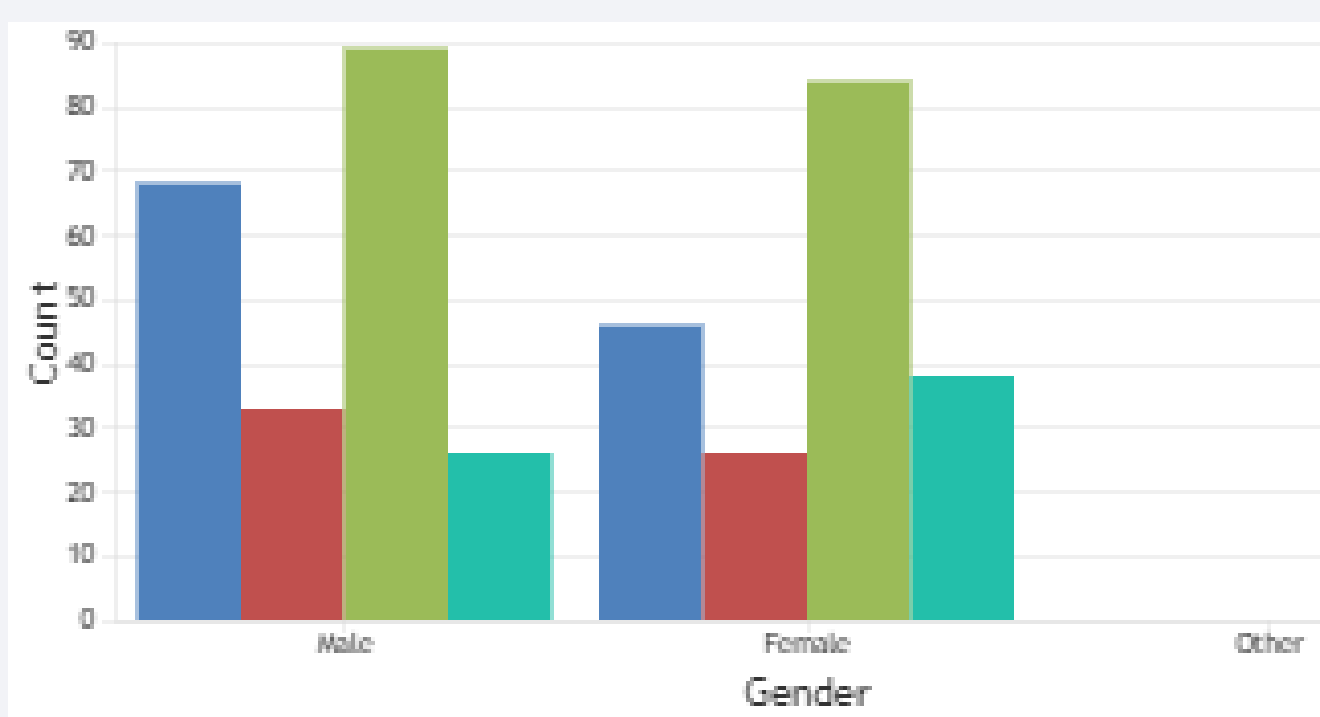

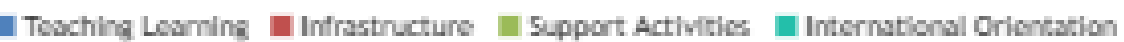

\section{CONCLUSION}

This study presents an enhancement to the existing ranking system in Indian context. The ranking parameters were identified from various ranking frameworks keeping in mind the 
Indian students and Universities. A methodology to generate the weights of the parameters dynamically as per preferences of different stakeholders has been proposed. A web portal for capturing the responses of the stakeholders, calculating weights of individual parameters and generating analytical reports has been implemented. The results of data analytics presented.

\section{ACKNOWLEDGEMENTS}

We are indebted to Director of Information and Library Network (INFLIBNET) Centre, Gandhinagar, Dr. Jagdish Arora for the intellectual support

\section{REFERENCES}

Alma, Büşra, Erman Coşkun, and Ezgi Övendireli. 2016. "University Ranking Systems and Proposal of a Theoretical Framework for Ranking of Turkish Universities: A Case of Management Departments." Procedia-Social and Behavioral Sciences 235: 128-38.

Gingrich, Paul. 2004. "Chi Square Tests." Introductory Statistics for the Social Sciences: 735-42.

Leung, K Ming. 2007. "Decision Trees and Decision Rules." : $1-13$.

Marguirite Clarke. 2007. "College and University Ranking Systems: Global Perspectives and American Challenges." College and University Ranking Systems: Global Perspectives and American Challenges: 35-47.

Swail, Watson Scott. 2011. "In Search of a Better Mousetrap: A Look at Higher Education Ranking Systems." College \& University 86(4): 28-33,.

(https://www.nirfindia.org).

http://www.hec.gov.pk/english/universities/Pag es/University-ranking.aspx http://www.qs.com/rankings/

https://www.timeshighereducation.com/worlduniversity-rankings

http://cwcu.sjtu.edu.cn/arwu.html
A SURVEY OF COLLEGE STUDENTS' PREFERENCES FOR HIGHER EDUCATION INSTITUTE FACILITIES

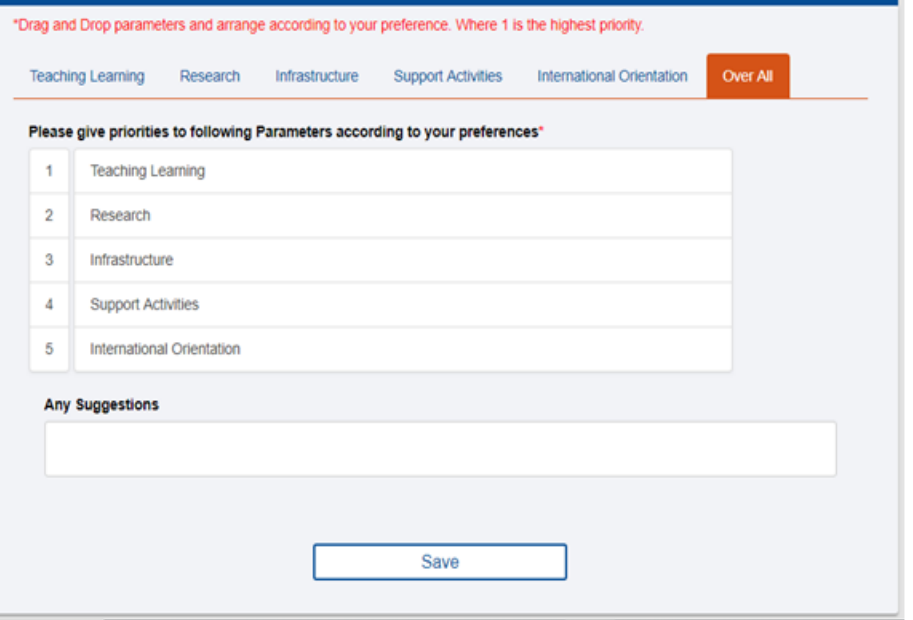

